\title{
EFFECTIVENESS OF TWO INSTRUCTIONAL METHODS ON REASONING ABILITY OF CHILDREN WITH HEARING IMPAIRMENT IN NIGERIA
}

\author{
Samuel Olufemi ADENIYI ${ }^{*}$ \\ Olaotan Oladele KUKU** \\ *University of Lagos, Department of Educational Foundation, Nigeria \\ ${ }^{* *}$ Federal College of Education (Technical), Akoka, Nigeria
}

Language has a noteworthy role in the cognitive development and social ability of an individual. However, a delay in language could affect an individual ability to think critically. This could be breached through impactful method of instruction from elementary school. Thus, this study examined the differential effectiveness of Montessori didactic and Direct Instructional methods on reasoning ability of children with hearing impairment in Lagos State.

The sample size was 29 pupils comprising 15 male and $14 \mathrm{fe}$ male pupils with hearing impairment. The Reasoning Ability Test was used to gather relevant data while mean, standard deviation, mean difference, Analysis of Covariance (ANCOVA) and Least Significant Difference (LSD) were the statistical tool used to analyse the data.

The study found that both Montessori Didactic Material and Direct Instruction method were efficacious in teaching pupils with hearing impairment. However, the former was more effective. The teaching methods do not have significant gender effect on pupils with hearing impairment. It was recommended that Montessori didactic method should be employed in teaching elementary school pupils because it encourages active participation in learning process in form of self-direction and independence not minding gender, intellectual and economic disparities.

Key words: Reasoning Ability, Montessori Didactic Instruction, Direct Instruction, Hearing Impairment

1 E-mail: safeadeniyi@yahoo.com 
Specijalna edukacija i rehabilitacija (Beograd), Vol. 17, br. 4. 395-417, 2018.

\section{INTRODUCTION}

Ability to take vital decision in life depends on good sense of judgment that results from internalisation of information from within and around one's environment. Good sense of judgment is the evidence of good reasoning. Edwards, Figueras, Mellanby, and Langdon (2010) expressed that cognitive development and abilities are dependent on language and language has long been considered an important underpinning to the reasoning process. This then means that rich language skill is a precursor for good reasoning ability in individuals. Research evidence supports that hearing loss has effect on child's language, social and cognitive development (Marschark \& Everhart, 1999, as cited in Laurent, 2014). It is generally believed that delay in key aspects of cognitive development is linked with delay language (Schick, De Villiers, De Villiers, \& Hoffmeister, 2007), this of course, presents itself in many deaf and hard of hearing children (Laurent, 2014). The reason for this is that language serves as tool and basis for inner thought. Hence, when language is delayed, the ability to think about situation critically is affected because of lack of internalization of spoken word due to auditory deprivation.

Given that majority of children with hearing impairment are at risk of delayed language development, it could be predicted that they would possess poor development or difficulties of inner speech and consequently difficulties in developing reasoning skills (Edwards, et al., 2011). Although, research on the cognitive abilities of deaf children have produced inconsistent findings, nevertheless, research in the field of deafness and deaf culture showed that deaf and hard of hearing students are approximately two years behind their hearing peers (Ashmore, 2017). This performance gap is an evidence of developmental and language difficulties among children and adults with hearing impairment. Studies on children adaptation revealed that language plays an important role in thought and reasoning (Loewenstein \& Gentner, 2005; Vygotsky, 2012). 
According to Vygotsky (2012), children use overt speech to work through problems in conjunction with elders, then learn to use language themselves privately while working through problems on their own, and eventually internalize with solving problems. However, on the part of children with hearing impairment a series of findings have shown that individuals with language deficit demonstrate deficit in reasoning and problem solving abilities (Baldo, Bunge, Wilson, \& Dronkers, 2010; Baldo et al., 2005) and the severity of language deficit is directly related to the level of cognitive impairment which evidently demonstrated itself in reasoning difficulties among children and adults with deafness (Baldo et al., 2010; Baldo et al., 2005). Therefore, if language is consequential to reasoning, there should be a way of bridging the gap of language deficit as it affects reasoning ability of children with hearing impairment in form of adequate and relevant instructional strategies that will motivate and promote good reasoning ability among these disadvantaged individuals.

Many researchers in the field of deaf studies are concerned with why there is this performance gap and in view of this a lot of approaches have been adopted in forms of behavioural and instructional interventions. The outcome of these interventions called for exploring more interventions and techniques that have yielded positives results among children that are not hearing impaired. Optimizing education at all levels is important for both economic and developmental standpoint (Blair \& Raver, 2016; Heckman, 2006) as this will reduce wastage and improve human resource development. Early educational intervention for disadvantaged individuals is a key to promoting holistic societal development. For children with hearing impairment, intervention(s) that will bring about total integration in all aspects of life especially the one that will improve academic and social development across intellectual differences, gender and economic disparities is expedient. Hence, the effectiveness of Montessori didactic and direct instructional methods needs to be explored, whether they can have a positive impact on reasoning ability of students with 
hearing impairment. So far the approaches have tested to be effective in improving academic achievement of students without hearing impairment.

Montessori instructional method was developed by Maria Montessori over 100 years ago. Central to Montessori Method of education is the dynamic triad of child, teacher and environment (Marshall, 2017). In this approach, teachers'roles are to guide the child through a prepared environment that is designed to support the child's intellectual, physical, emotional and social development through active exploration, choice and independent learning (Marshall, 2017; Randolph, Rosenstein \& Michaels, 2014). In Montessori learning strategy, learning materials are developed in an interactive way to support children's learning of sensorial concepts such as dimension, color, shape and texture and academic concepts of Mathematics, literacy, science, geography and history and children are made to learn by engaging hand-on with the materials most often individually, in pairs or small groups. This aspect of learning by manipulation and engagement encourage exploration which motivate ability to think, reason and to be self-directional later in life. Lillard (2005) in line with exploratory and engagement as espoused by Marshall (2017) and Randolph et al. (2014) outlined eight Montessori principles that the organized learning environment must uphold to accomplish the goal of nurturing and optimizing students learning. They stated that learning environment must be conducive and take into consideration students' choice, interest as well as avoidance of extrinsic reward. In addition, collaborative and cooperative learning, context-dependent learning, teacher models and student methods are well fashioned to aid effective learning. The listed principles and guides must be presented in a typical Montessori class. This is a clear indication of a class that is the least restrictive and more student-centered and exploratory. The above principles were also supported by Nunnery, Chappell and Arnold (2013) who stated that when entering a Montessori classroom, the display by teachers demonstrate events and problems situated within 
daily life such as housekeeping, art, cooking, gardening and experimenting and students are facilitated creatively to solve problems as well as determine the lessons that can be derived from them.

Arguably, studies have reveled strengths and weaknesses of Montessori didactic instruction within the last 100years of its existence. For instance, Lillard and Else-Quest (2016) evaluated Montessori education by comparing children of Montessori and non-Montessori education from different age groups on a range of cognitive, academic, social and behavioural measures, the result demonstrated significant differences between Montessori and non-Montessori groups in which the efficacies of former method was highly felt in the areas of Mathematics skills, phonological decoding ability and social skills. In a related study by Brown (2016) on evaluating the effectiveness of Montessori reading and Mathematics instruction for third grade African-American students in urban elementary school, the result revealed that Montessori group achieve a higher level of reading which suggests that the method can be an effective pedagogy, although no statistically significant effect of this method was recorded in Mathematics compared with other magnet programme. Furthermore, Vance (2003), in an exploratory study of relationship between pre-school experience and acquisition of phonological awareness in Kindergarten using Montessori Method, revealed that Montessori pre-school significantly outscored all other preschools operating under different philosophies. Also, MdYunus and Peng (2014) in their investigation on "Do students in Montessori school perform better in achievement test in Taiwan?" revealed a significantly higher score in language arts and Mathematics. However, Shen (2005) compared two groups of students, that is, those who attended Montessori and those who did not. It was found that those who did not attended Montessori method of instruction perform better than their pairs who attended. Shen (2005) further found that children from non-Montessori programme had better abilities in Mathematics concept of numerals, calculation and 
application than their peers in Montessori programmes. But Lopata, Wallace and Finn (2005) reported a different finding while comparing children from Montessori and traditional programme among different grade levels and found no significant difference in academic achievement in language and Mathematics among the participants. In the same vein, Mallett and Schroeder (2015), in their study on academic achievement outcome of Montessori and non-Montessori public elementary schools, found no significant difference in the performance of the two groups.

Regarding gender implication in Montessori didactic method, there were fewer studies which have taken cognizance of this variable. Nevertheless, studies by Dhiksha and Shivakumara (2017) on the effect of Montessori and traditional methods of education on emotional intelligence of children reported that Montessori female children have higher selfregard and empathy toward others than male children though this result is not generalizable and did not directly reflect cognitive benefits between male and female participants. But from far reaching evidence, Montessori method has demonstrated immediate and potential benefits since its advent some 100 year ago.

On the other hand, Direct Instruction method is a strategy typically focusing on accomplishing instructional targets by providing training on skills that are closely related to the targets. In Directs Instruction, lessons are well planned, neat and organized around small learning increments and clearly defined and prescribed teaching task (National institute for Direct Instruction, 2007). The most significant gain of this pedagogy is that it provides a means of efficiently communicating large amount of information within a short period of time to students (Cohen, 2008). Direct Instruction Strategy was developed by Engelmann, Bereiter and Becker in late 1960s at the University of Illinois and was first implemented as Direct instruction system for teaching and remediation consisting of programmes addressing reading, language and Mathematics (Magliaro, Lockee, \& Burton, 2005). 
Literature revealed that Direct Instruction method was developed as a result of many arguments and thought predicated on skills and system analysis, social behavioural modeling and teacher-centered research studies (Al-Makahleh \& Abdul-Hameed, 2011). This teaching strategy is rooted in behavioural theory of what Skinner referred to as radical or selectionist behaviourism as it involves behaviour selected by the consequences which follow them (Magliaro et al., 2005). The strategy focuses on procedures followed by teachers and the curriculum and identifies specifically and explicitly what skills needed to be learnt step by step instead of leaving students on their own experience (Kinder, Kubina, \& Marchand-Martella, 2005).

Direct Instruction strategy is based on the assumption that disadvantaged children meet up with their peers if instructors are effective and efficient. In this way, the unique needs of low achievers who struggle for achievement can adequately be met in diverse areas of needs. This is because the strategy is meant to accelerate students' progress with the aim of achieving mastery and reflective accuracy. In achieving these, there are steps involved. The steps are to be followed strictly with a lot of caution. They include: measuring students' performance directly and accurately while concentrating on basic concepts much needed by student, goals are set accurately, operationally formulated so as to introduce final behaviour expected from student, instructional tasks are analyzed and elements are sequentially and systematically arranged, sufficient time is allocated for task learning, feedback is provided for students, students are instructed to practice the mastered task more, students' performance is displayed in suitable graphical form and students must be provided with appropriate problem solving form with supports and practices that match specific skills (Al-Makahleh \& Abdul-Hameed, 2011).

Direct instruction has been reported to be efficacious in a number of skills needed by students. For instance, Oladayo and Oladayo (2012) used Direct and Indirect Instruction strategies on students' achievement in Mathematics in Nigeria. The 
result of the study revealed that experimental group subjected to direct instruction out-performed their peers in Indirect and control groups. In the same vein, Al-Makahleh and AbdulHameed (2011) examined the effect of direct instruction strategy on Mathematics achievement of Primary $4^{\text {th }}$ and $5^{\text {th }}$ grade students with learning difficulties. They reported a significant effect of Direct Instruction strategy on basic skills achievement among $4^{\text {th }}$ and $5^{\text {th }}$ grade students with learning difficulties. Also, Adams and Engelmann (1996) reviewed 34 separate studies out of which $87 \%$ of the results favored the use of Direct Instruction as a means of aiding achievement of students. Several similar case studies have also reported efficacies of Direct Instruction on their subjects (Goral, 2001; Graves, 2002; Miller, 2001; Wilson, 2003). However, López, Torrance, Rijlaarsdam and Fidalgo (2017), in their study on effects of direct instruction and strategy modelling on upperprimary students' writing development, reported no significant difference in the two experimental groups. By implication, both Direct Instruction and Strategy Modelling are equally effective.

In addition, studies have also revealed gender implication as regards direct instruction method. Among these studies is Oladayo and Oladayo (2012) whose study investigated the effect of direct and indirect instructional strategies on students' achievement in Mathematics. The results among others revealed that gender significantly determined the effect of direct instructional strategy with male students responding more positively to direct instruction than their female peers.

Obviously both Montessori and direct instructional strategies have proved to be effective teaching methods at one time or the other on different categories of students who are not hearing impaired both in Nigeria and other countries around the globe. However, there are scanty empirical studies that have reported the use of both methods as early intervention strategies to improve academic challenges of pupils or students with hearing impairment both locally and internationally to the best of researchers' knowledge. Hence, there is the need to 
explore their effectiveness in improving reasoning abilities of pupils with hearing impairment with the aim of helping them to develop high level cognitive activities. This study therefore examined differential effectiveness of Montessori didactic and direct instructional methods on reasoning ability of children with hearing impairment in some special schools in Lagos, Nigeria.

\section{RESEARCH HYPOTHESES}

The following research hypotheses were formulated to guide the study and tested.

1. Reasoning ability mean score of pupils do not significantly differ among hearing impaired in inclusive schools taught with Montessori didactic material, direct instruction method and the control group.

2. Reasoning Ability mean scores do not significantly differ among pupils with hearing impairment taught with Montessori didactic material, direct instruction method and the control group due to gender.

\section{METHODOLOGY}

\section{Research Design}

The research design adopted for this study is a quasiexperimental pretest/posttest control group research design.

\section{Population of the Study}

The population of the study consisted of all primary school pupils with hearing impairment in Lagos State. 
Specijalna edukacija i rehabilitacija (Beograd), Vol. 17, br. 4. 395-417, 2018.

\section{Sample and Sampling Technique}

A sample size of 29 elementary school pupils consisting of 15 male and 14 female pupils with hearing impairment was used for the study. Their ages range between 7 and 9 years because of the peculiar nature of their disability that may cause developmental delay as well as making them start school later than their hearing peers. The participants were primary two pupils with hearing impairment. The sample was selected through simple random and purposive sampling techniques. Simple random sampling, hat and draw method was used to three Local Government Areas in Lagos State. The locations of the research were based on where special schools for students with hearing impairment are situated. The next stage involved using purposive sampling technique to select one special school in each of the three Local Government Areas. The last stage of the sampling technique involved using simple random sampling, hat and draw method to select one intact class of primary 2 pupils with hearing impairment in each of the three schools previously selected in each of the Local Government Areas.

Simple random sampling technique was used to randomly assign the schools to the experimental groups. There were three experimental groups namely: Montessori Didactic Materials, Direct Instruction Method and Control Group. School A was randomly assigned to Montessori Didactic Materials teaching method, while School B and C were assigned to Direct Instruction teaching method and Control Group respectively. Table 1 shows the number of participants across the groups that constitute the baseline assessment and experiment. Primary two pupils were used for this study because the researchers believed that the two instructional strategies could assist in early intervention of learning problems that pupils with hearing impairment are confronted with. 
Adeniyi, S.O., Kuku, O.O.: Effectiveness of two instructional methods on reasoning ability of children with hearing impairment in Nigeria

Table 1 - Distribution of Pupils across Gender, Baseline Assessment and Experimental Group

\begin{tabular}{lccclccc}
\hline \multirow{2}{*}{ School } & \multicolumn{3}{c}{ Baseline Assessment } & \multirow{2}{*}{ Group } & \multicolumn{3}{c}{ Experimental Group } \\
\cline { 2 - 7 } & Male & Female & Total & Male & Female & Total \\
\hline School A & 5 & 6 & 11 & $\begin{array}{l}\text { Montessori } \\
\text { Didactic Material }\end{array}$ & 4 & 5 & 9 \\
\hline School B & 6 & 6 & 12 & Direct Instruction & 5 & 5 & 10 \\
\hline School C & 7 & 5 & 12 & Control Group & 6 & 4 & 10 \\
\hline Total & 18 & 17 & 35 & Total & 15 & 14 & 29 \\
\hline
\end{tabular}

Observation from Table 1 shows that the study started with three schools and 35pupils consisting of 18 male and 17 female pupils for baseline assessment. The baseline criterion for qualification for the experimental condition was a score less than $40 \%$ in the Reasoning Ability Test (RAT). After the baseline test, 29 pupils consisting of 15 male and 14 female participants qualified for the study.

Instrument

The Reasoning Ability Test (RAT) was the instrument used to gather data for this study. The instrument was adapted from Letts verbal, non-verbal and quantitative reasoning text for age 6 . The adapted instrument had three sections, namely: non-verbal, verbal and quantitative reasoning. The 30-item RAT was a multiple choice test. The non-verbal reasoning section had 10 items, the verbal reasoning section had 10 items and the quantitative reasoning also had 10 items. The RAT had a minimum and maximum obtainable score of 0 and 20 respectively. A pilot study was conducted in a different school that was not used for the main study in order to derive the psychometric property of RAT.

The validity of RAT was ensured using concurrent validity. The scores generated from the original and adapted instrument were subjected to Pearson Person Product Moment Correlation Coefficient. A correlation coefficient of 0.77 was derived while test retest reliability was used to ensure the stability of the instrument. A reliability coefficient of 0.83 was derived from the process. 
Specijalna edukacija i rehabilitacija (Beograd), Vol. 17, br. 4. 395-417, 2018.

\section{Administration of \\ Instrument/Data Collection}

The experiment duration was 9 weeks. The experiment was conducted in three phases, namely: pretesting phase, treatment phase and post testing phase. The testing phase involved introduction, familiarization and administration of the RAT. The selected schools for the study were visited at this stage and the researchers introduced themselves to the schools' administrators, non-teaching and teaching members of staff. The researchers also met with the pupils during the familiarization process to have close affinity with the pupils. Thereafter, a baseline assessment was conducted by the researchers with the use of RAT. The RAT was administered to a total sample size of 35 pupils in the three schools. There were 11,12 , and 12 pupils in schools $\mathrm{A}, \mathrm{B}$, and $\mathrm{C}$ respectively, who were involved in the baseline assessment. The aim of the pretesting was to ensure that the level of reasoning abilities among the sample were below $40 \%$ score in RAT. After the baseline assessment, School A was left with nine pupils and was randomly assigned the Montessori Didactic Material Group; School B was left with 10 pupils and was randomly assigned the Direct Instruction Group; while School C was left with 10 pupils and was randomly assigned the Control Group. A total of 29 pupils qualified for the study and the details of their distribution across gender, school and experimental groups can be found in Table 1 .

The treatment phase involved the teaching of the three experimental groups based on the different teaching methods. School A was taught using the Montessori Didactic method, School B was taught using the Direct Instruction method while School C, which is Control Group was exposed to the conventional teaching method.

The post testing phase was the last phase in the experimental process that involved the re-administration of the RAT to the respective groups. 
Adeniyi, S.O., Kuku, O.O.: Effectiveness of two instructional methods on reasoning ability of children with hearing impairment in Nigeria

\section{Method of Data Analysis}

The data gathered were analysed using descriptive and inferential statistics. The descriptive statistics used involved mean, standard deviation and mean differences while the inferential statistics used were Analysis of Covariance (ANCOVA) and LSD multiple comparison test. The hypotheses were tested at 0.05 level of significance.

\section{Obtained Results}

Hypothesis 1: Reasoning ability mean score of pupils do not significantly differ among hearing impaired in inclusive schools taught with Montessori didactic material, direct instruction method and the control group.

To test hypothesis 1, a descriptive statistics, an Analysis of Covariance (ANCOVA) and a pairwise comparison results are presented in Tables 2, 3 and 4 respectively.

Table 2 - Descriptive Data on Pretest and Posttest Scores on Reasoning Ability among pupils exposed to the Experimental condition

\begin{tabular}{lcccccc}
\hline \multirow{2}{*}{$\begin{array}{l}\text { Experimental } \\
\text { Group }\end{array}$} & $\mathrm{N}$ & \multicolumn{2}{c}{ Pre-Test } & \multicolumn{2}{c}{ Post-Test } & Mean \\
\cline { 3 - 6 } & & Mean & $\begin{array}{c}\text { Std. } \\
\text { Deviation }\end{array}$ & Mean & $\begin{array}{c}\text { Std. } \\
\text { Deviation }\end{array}$ & $\begin{array}{c}\text { Difference } \\
\text { Montessori }\end{array}$ \\
Didactic Material & 9 & 37.67 & 2.35 & 48.89 & 6.51 & 11.22 \\
\hline Direct Instruction & 10 & 36.50 & 3.84 & 47.60 & 5.06 & 11.10 \\
\hline Control Group & 10 & 35.90 & 1.45 & 40.20 & 5.67 & 4.30 \\
\hline Total & 29 & 36.66 & 2.74 & 45.45 & 6.78 & 8.79 \\
\hline
\end{tabular}

Observation from Table 2 shows that the mean reasoning ability at pretest was 37.67, 36.50 and 35.90 for Montessori didactic material, direct instruction and control group respectively. At posttest, the mean reasoning ability rose to 48.89 for Montessori didactic material group, 47.60 for direct instruction and 40.20 for control group. It could be observed that the mean difference of Montessori didactic material with 11.22 and direct instruction group with 11.10 were above the 
Specijalna edukacija i rehabilitacija (Beograd), Vol. 17, br. 4. 395-417, 2018.

total mean difference of 8.79. In order to determine the level of significance, the Analysis of Covariance (ANCOVA) was used and the result is presented in Table 3.

Table 3 - ANCOVA on Reasoning Ability among the Experimental Groups

\begin{tabular}{lccccc}
\hline Source & Sum of Squares & Df & Mean Square & F & Sig. \\
\hline Corrected Model & 437.254 & 3 & 145.751 & 4.287 & 0.014 \\
\hline Intercept & 205.310 & 1 & 205.310 & 6.039 & 0.021 \\
\hline Covariate & 8.970 & 1 & 8.970 & 0.264 & 0.612 \\
\hline Experimental Group & 380.325 & 2 & 190.163 & 5.594 & 0.010 \\
\hline Error & 849.918 & 25 & 33.997 & & \\
\hline Total & 61188.000 & 29 & & & \\
\hline Corrected Total & 1287.172 & 28 & & & \\
\hline
\end{tabular}

*Significant at $\mathrm{p}<0.05 ; \mathrm{F}$-critical at $0.05(2,25)=4.01$

Figures from Table 3 show that an F-calculated value of 5.594 , with $\mathrm{p}=0.010$, resulted as the effect of the experimental condition on the reasoning ability of hearing impaired students in inclusive schools in Lagos State. The F-calculated value of 5.594 was found to be greater than 4.01 given degree of freedom 2 and 25 at 0.05 level of significance. Consequently, the null hypothesis was rejected. It was concluded that reasoning ability mean scores of pupils with hearing impairment in special school in Lagos State differ among those exposed to the different experimental condition. In order to determine the groups that differ, a pairwise comparison analysis was conducted and the result is presented in Table 4.

Table 4 - A Pairwise Comparison of Experimental Groups based on Reasoning Ability

\begin{tabular}{llcc}
\hline Experimental Group (I) & Experimental Group $(J)$ & Mean Difference $(\mathrm{I}-\mathrm{J})$ & $\mathrm{p}$ \\
\hline Montessori Didactic & Direct Instruction & 1.039 & 0.706 \\
\cline { 2 - 4 } Material & Control Group & $8.310^{*}$ & 0.006 \\
\hline \multirow{2}{*}{ Direct Instruction } & $\begin{array}{l}\text { Montessori Didactic } \\
\text { Material }\end{array}$ & -1.039 & 0.706 \\
\cline { 2 - 4 } & Control Group & $7.271^{*}$ & 0.01 \\
\hline \multirow{2}{*}{ Control Group } & $\begin{array}{l}\text { Montessori Didactic } \\
\text { Material }\end{array}$ & $-8.310^{*}$ & 0.006 \\
\cline { 2 - 4 } & Direct Instruction & $-7.271^{*}$ & 0.01 \\
\hline
\end{tabular}

*Significant at $p<0.05$ 
Table 4 indicates that pupils with hearing impairment in inclusive schools in Lagos State taught with Montessori Didactic Material ( $\mathrm{t}=-8.310 ; \mathrm{p}<0.05)$ and Direct Instruction ( $\mathrm{t}=-7.271$; $\mathrm{p}<0.05$ ) groups were significantly better than their peers in the control group. This shows that Montessori Didactic Method group and Direct Instruction group have substantial effects on the reasoning ability of pupils with hearing impairment when compared with the control group.

Hypothesis 2: Reasoning Ability mean scores do not significantly differ among pupils with hearing impairment taught with Montessori Didactic Method, direct instruction method and the control group due to gender.

To test hypothesis 2, a descriptive statistics and an Analysis of Covariance (ANCOVA) results are presented in Tables 5 and 6 respectively.

Table 5 - Descriptive Data on effect of Experimental condition and Gender on Reasoning Ability

\begin{tabular}{|c|c|c|c|c|c|c|c|}
\hline \multirow{2}{*}{$\begin{array}{l}\text { Experimental } \\
\text { Group }\end{array}$} & \multirow[b]{2}{*}{ Gender } & \multirow[b]{2}{*}{$\mathrm{N}$} & \multicolumn{2}{|c|}{ Pre-Test } & \multicolumn{2}{|c|}{ Post-Test } & \multirow{2}{*}{$\begin{array}{c}\text { Mean } \\
\text { Difference }\end{array}$} \\
\hline & & & Mean & $\begin{array}{c}\text { Std. } \\
\text { Deviation }\end{array}$ & Mean & $\begin{array}{c}\text { Std. } \\
\text { Deviation }\end{array}$ & \\
\hline \multirow{3}{*}{$\begin{array}{l}\text { Montessori } \\
\text { Didactic } \\
\text { Material }\end{array}$} & Male & 4 & 37.25 & 3.20 & 50.00 & 10.00 & 12.75 \\
\hline & Female & 5 & 38.00 & 1.73 & 48.00 & 2.74 & 10.00 \\
\hline & Total & 9 & 37.67 & 2.35 & 48.89 & 6.51 & 11.22 \\
\hline \multirow{3}{*}{$\begin{array}{l}\text { Direct } \\
\text { Instruction }\end{array}$} & Male & 5 & 36.60 & 4.16 & 49.20 & 4.60 & 12.60 \\
\hline & Female & 5 & 36.40 & 3.97 & 46.00 & 5.47 & 9.60 \\
\hline & Total & 10 & 36.50 & 3.84 & 47.60 & 5.05 & 11.10 \\
\hline \multirow{3}{*}{$\begin{array}{l}\text { Control } \\
\text { Group }\end{array}$} & Male & 6 & 36.00 & 1.55 & 38.17 & 5.31 & 2.17 \\
\hline & Female & 4 & 35.75 & 1.50 & 43.25 & 5.38 & 7.50 \\
\hline & Total & 10 & 35.90 & 1.45 & 40.20 & 5.67 & 4.30 \\
\hline \multirow{3}{*}{ Total } & Male & 15 & 36.53 & 2.88 & 45.00 & 8.43 & 8.47 \\
\hline & Female & 14 & 36.79 & 2.69 & 45.92 & 4.70 & 9.13 \\
\hline & Total & 29 & 36.66 & 2.74 & 45.45 & 6.78 & 8.79 \\
\hline
\end{tabular}

Observations from Table 5 show that at pretest, reasoning ability of male participants were $37.25,37.67$ and 36.00 for Montessori Didactic Method, Direct Instruction and Control Group respectively. The female participants' reasoning ability 
Specijalna edukacija i rehabilitacija (Beograd), Vol. 17, br. 4. 395-417, 2018.

was 38.00 for Montessori Didactic Material, 36.40 for Direct Instruction and 35.75 for Control Group.

At post-test, the male participants had 50.00 for Montessori Didactic Material, 49.20 for Direct Instruction and 38.17 for Control Group. The female participants had 48.00, 46.00 and 43.25 for Montessori Didactic Method, Direct Instruction and Control Group respectively. The mean differences in reasoning ability of male participants show that Montessori Didactic Material (12.75) and Direct Instruction method (12.60) were above the male total of 8.47. However, the male participants in Montessori Didactic Method had a better reasoning ability than the Direct Instruction group. Similarly, the mean differences in reasoning ability of female participants show that Montessori Didactic Method (10.00) and Direct Instruction method (9.60) were above the female total of 9.13. The female participants in Montessori Didactic Method had a better reasoning ability than the Direct Instruction group. To ascertain the level of significance, the Analysis of Covariance (ANCOVA) was used and the results are presented in Table 6.

Table 6 - ANCOVA Result for Experimental Condition and Gender on Reasoning Ability

\begin{tabular}{lrrrrr}
\hline Source & $\begin{array}{r}\text { Sum of } \\
\text { Squares }\end{array}$ & Df & $\begin{array}{r}\text { Mean } \\
\text { Square }\end{array}$ & F & Sig. \\
\hline Corrected Model & 536.013 & 6 & 89.335 & 2.616 & 0.046 \\
\hline Intercept & 195.892 & 1 & 195.892 & 5.737 & 0.026 \\
\hline Covariate & 11.223 & 1 & 11.223 & 0.329 & 0.572 \\
\hline Group & 325.722 & 2 & 162.861 & 4.770 & 0.019 \\
\hline Gender & 0.028 & 1 & 0.028 & 0.001 & 0.977 \\
\hline Experimental Groups * Gender & 98.740 & 2 & 49.370 & 1.446 & 0.257 \\
\hline Error & 751.160 & 22 & 34.144 & & \\
\hline Total & 61188.000 & 29 & & & \\
\hline Corrected Total & 1287.172 & 28 & & & \\
\hline *Significant at $\mathrm{p}<0.05 ;$ F critical at $0.05(2,22)=4.01$ & & &
\end{tabular}

The figures from Table 6 show that an F-calculated value of 1.446 , with $p$-value $=0.257$, resulted as the effect of the experimental condition on the reasoning ability of hearing impaired pupils in special schools in Lagos State due to gender. The F-calculated value of 1.446 was found to be less than 4.01 
given degree of freedom 2 and 22at 0.05 level of significance. As a result, the null hypothesis was retained and it was concluded that Reasoning Ability of students does not significantly differ among pupils with hearing impairment in special schools taught with Montessori Didactic Method, direct instruction method and the control group due to gender.

\section{DISCUSSION OF FINDINGS}

The findings of this study revealed that Montessori Didactic and Direct instruction strategies have a great and positive impact on reasoning ability of pupils with hearing impairment in special schools in Lagos State, Nigeria. The reasons for this could be attributed to the interactive nature of Montessori Didactic instructional design that involves active participation of students/pupils and Direct instruction method which involves step by step mastery of skills with a well stated procedure to be followed by teachers. These of course will help the pupils with hearing impairment to be able to develop sense of identity and positive cognitive behaviour. This finding corroborated many previous studies on the two instructional strategies. For instance, Brown (2016) on evaluating the effectiveness of Montessori reading and Mathematics instruction for third grade African-American students in urban elementary school, revealed that Montessori group achieve a higher level of reading which suggests that the method can be an effective pedagogy, although no statistically significant effect of this method was recorded in Mathematics compared with other magnet programme. In the same vein, Md-Yunus and Peng (2014) in their investigation on "Do students in Montessori school perform better in achievement test in Taiwan?" revealed a significantly higher score in language arts and Mathematics among subjects exposed to Montessori Instruction. The outcomes of these findings are evidences that Montessori didactic instruction is greatly efficacious in improving academic behaviour of learners. Also, 
Direct Instruction method has also been widely reported to have great influence on different domain of human activities. Studies by Oladayo and Oladayo (2012) on the use of direct and indirect instruction strategies on students' achievement in Mathematics in Nigeria revealed that experimental group subjected to direct instruction out-performed their peers in indirect and control groups. The impact of these two strategies is an eye opener to the dynamism and innovation that must be encouraged in teaching so as to bring the best out of individuals that society would have written off. Nevertheless, there were studies which reported contrarily to the findings above. Reports like these give room for further research and thorough investigation in the area of pedagogical innovation and environmental implications. In addition, the post-hoc analysis revealed that Montessori Didactic Method is more efficacious between the two strategies. The reason for this may be attributed to the fact that this aspect of learning by manipulation and engagement encourages exploration which motivates ability to think, reason and to be self-directional later in life (Marshall, 2017; Randolph et al., 2014). Unfortunately, despite the benefits of the two instructional strategies among non-disabled pupils, there are scanty studies on effectiveness of these pedagogies on academic behaviour of students with hearing impairment locally.

The finding further revealed that reasoning ability of pupils with hearing impairment in special school in Lagos taught with Montessori didactic strategy, direct instruction method and the control group does not significantly differ due to gender. The reason can be attributed to the fact that the groups are affected with the same problem not minding their gender disparities. This finding is contrary to some studies that have reported the influence of some interventions due to gender. For instance, Dhiksha and Shivakumara(2017), in their study on the effect of Montessori and traditional methods of education on emotional intelligence of children, reported that Montessori female children have higher selfregard and empathy toward others than male children. Also, 
Oladayo and Oladayo (2012) investigated the effect of direct and indirect instructional strategies on students' achievement in Mathematics. The results among others revealed that gender significantly determined the effect of direct instructional strategy with male students responding more positively to direct instruction than their female peers. The finding cannot be dissociated from the influence of environment and other personal-social constructs.

\section{CONCLUSION}

This study investigated differential effectiveness of Montessori Didactic and Direct Instructional Methods on reasoning ability of children with hearing impairment in Nigeria. From the result it was found that Montessori Didactics and Direct Instruction methods of teaching yielded impactful outcome on the reasoning ability of children with hearing impairment. In addition, the study showed that gender had no effect on pupils reasoning ability irrespective of the teaching method.

\section{Recommendations}

The results of the study bring to bear that Montessori DidacticandDirectinstructionalmethodsshouldbeencouraged as pedagogical tools to be used by teachers of pupils with hearing impairment. More importantly, Montessori Didactic method should be more employed in teaching elementary school pupils because it encourages active participation in the learning process in form of self-direction and independence not minding gender, intellectual and economic disparities. 
Specijalna edukacija i rehabilitacija (Beograd), Vol. 17, br. 4. 395-417, 2018.

\section{REFERENCES}

1. Adams, G., Engelmann, S. (1996). Research on direct instruction: 25 years beyond DISTAR. Seatle, W.A: Educational Achievement System, 319 Nickerson Street Suite 112, Seattle, WA 98109.

2. Al-Makahleh, A., \& Abdul-Hameed, A. (2011).The effects of direct instruction strategy on math achievement of primary $4^{\text {th }}$ and $5^{\text {th }}$ grade students with learning difficulties. International Education Studies, 4(4), 199-205. doi: 10.5539/ies.v4n4p.199.

3. Ashmore, B. (2017). A study of the performance of deaf/heard of hearing students in high school mathematics on conceptual understanding procedural fluency and Mathematical reasoning tasks. The colleges at Brockport: State University of New York.

4. Baldo, J. V., Bunge, S. A., Wilson, S. M., \& Dronkers, N. F. (2010). Is relational reasoning dependent on language? A voxel-based lesson symptom mapping study. Brian and language, 113(2), 5964. doi:10.1016/j.bandl.2010.01.004

5. Baldo, J. V., Dronkers, N. F., Wilkins, D., Ludy, C., Raskin, P., \& Kim, J. (2005). Is problem solving dependent on language? Brain and Language, 92(3), 240-250. doi:10.1016/j.bandl.2004.06.103.

6. Blair, C., \& Raver, C. C. (2016). Poverty stress and brain development: A new direction for brain development and intervention. Academy Pediatrics, 16(3), 30-36. doi:10.1016/j.acap.2016.01.010

7. Brown, K. E. (2016). Evaluating the effectiveness of Montessori reading and Math instruction for third grade African American students in urban elementary schools. (Unpublished Ph.D. dissertation) Charlotte, University of North Carolina

8. Cohen, M. T. (2008). The effect of direct instruction versus discovering learning on the understanding of science lessons by second grade students. The graduate center, city University of New York.

9. Dhiksha, J., \& Shivakumara, K. (2017). The effect of Montessori and traditional methods of education on emotional intelligence of children. European Journal of Education Studies, 3(4), 367-382. doi: 10.5281/zenodo. 399050

10. Edwards, L., Figueras, B., Mellanby, J., \& Langdon, D. (2010). Verbal and spatial analogical reasoning in deaf and hearing children: The 
Adeniyi, S.O., Kuku, O.O.: Effectiveness of two instructional methods on reasoning ability of children with hearing impairment in Nigeria

role of grammar and vocabulary. Journal of Deaf Studies and Deaf Education, 16(2), 189-197. doi: 10.1093/deafed/enq051

11. Goral, T. (2001). The fight about reading. Curriculum Administrator, $37(5), 35-40$.

12. Graves, B. (2002). Charter school's contract, name gives Portland pause. The OregonianB, 4.

13. Heckman, J. J. (2006). Skill formation and the economics of investing in disadvantaged children. Science, 312(5782), 1900-1902. doi: 10.1126/science.1128898

14. Kinder, D., Kubina, R., \& Marchand-Martella, N. (2005). Special education and direct instruction: an effective combination. Journal of Direct Instruction, 5(1), 1-36.

15. Laurent, A. T. G. (2014). An analysis of problem solving skills of children who are deaf or hard of hearing. (Unpublished M.Sc. Thesis) Washington University of Medicine. St Louis.

16. Lillard, A., \& Else-Quest, N. (2006). The early years: Evaluating Montessori education. Science, 313(5795), 1893-1894.

17. Lillard, A. S. (2005). Montessori: The science behind the genius. New York: Oxford University Press.

18. Loewenstein, J., \& Gentner, D. (2005). Relational language and development of relational mapping. Cognitive Psychology, 50(4), 315-353. doi:10.1016/j.cogpsych.2004.09.004

19. Lopata, C., Wallace, N. V., \& Finn, K. V. (2005).Comparison of academic achievement between Montessori and traditional education programs. Journal of Research in Childhood Education, 20(1), 5-13. doi:10.1080/02568540509594546

20. López, P., Torrance, M., Rijlaarsdam, G., \& Fidalgo, R. (2017). Effects of Direct Instruction and Strategy Modeling on UpperPrimary Students' Writing Development. Frontiers in Psychology, 8, 1054, doi:10.3389/fpsyg.2017.01054

21. Magliaro, S. G., Lockee, B. B., \& Burton, J. K. (2005). Direct instruction revisited: A key model for instructional technology. Journal of Educational Research Technology and Development, 53, 41-55. doi.10.1007/BF02504684

22. Mallett, J. D., \& Schroeder, J. L. (2015). Academic achievement outcomes: A comparison of Montessori and non-Montessori public 
Specijalna edukacija i rehabilitacija (Beograd), Vol. 17, br. 4. 395-417, 2018.

elementary school students. Journal of Elementary Education, 25(1), 39-53.

23. Marshall, C. (2017). Montessori education: A review of the evidence base. Science of Learning, 2(1), 11. doi:10.1038/s41539-017-0012-7.

24. Md-Yunus, S., \& Peng, H.H. (2014). Do students in Montessori school perform better on achievement test? A Taiwanese perspective. Early Childhood, Elementary and Middle Level Education, 1-21.

25. Miller, R. J. (2001). Controversial teaching technique winning fans in Sto-Rox Schools. Pittsburgh Post-Gazette, West Edition, 7.

26. National Institute for Direct Instruction (2007). What is direct instruction? Retrieved from http://www.nifdi.org/

27. Nunnery, J., Chappell, S., \& Arnold, P. (2013). A meta-analysis of a cooperative learning style model's effects on student achievement in mathematics. Cypriot Journal of Educational Sciences, 8(1), 34-38.

28. Oladayo, O. T., \& Oladayo, C. E. (2012). Effects of Direct and Indirect Instructional Strategies on Students' Achievement in Mathematics. African Research Review, 6(4), 349-361. doi.org/10.4314/afrrev.v6i4.24.

29. Randolph, J. M., Rosenstein, D. L. W., \& Michaels, S. (2014). Montessori education for improving academic and behavioral outcomes among elementary students. The Campbell Collaboration.

30. Schick, B., De Villiers, P., De Villiers, J., \& Hoffmeister, R. (2007). Language and Theory of Mind: A study of Deaf Children. Child development, 78(2), 376-396. doi:10.1111/j.1467-8624.2007.01004.x

31. Shen, W. (2005). To compare children mathematics ability who graduates from the Connon preschool and Montessori school in Tainan city. Child Care Science, 11(6), 34-53.

32. Vance, T. L. (2003). An exploration of the relationship between preschool experience and the acquisition of phonological awareness in kindergarten. (Dissertation George Mason University).

33. Vygotsky, L. S. (2012). Thought and language. Cambridge, M.A: MIT Press.

34. Wilson, K. (2003). Effective reading program must go: school's success story isn't on state book list. Ventura County, 01. 


\title{
UTICAJ DVA NASTAVNA METODA NA SPOSOBNOST RASUĐIVANJA KOD DECE SA OŠTEĆENJEM SLUHA U NIGERIJI
}

\author{
Samuel Olufemi ADENIY*, Olaotan Oladele KUKU** \\ "Univerzitet u Lagosu, Odsek za osnove obrazovanja, Nigerija \\ ${ }^{*}$ Savezni koledž za obrazovanje (Tehnički), Akoka, Nigerija
}

\section{Sažetak}

Jezik ima značajnu ulogu u kognitivnom razvoju i društvenoj kompetenciji pojedinca, a kašnjenje u razvoju jezika može uticati na sposobnost kritičkog rasuđivanja. Pomenuto kašnjenje bi se moglo preduprediti efikasnim nastavnim metodama u osnovnoj školi, pa je stoga u ovom istraživanju ispitan uticaj Montesori didaktičkog metoda i metoda Direktnog podučavanja na sposobnost rasuđivanja kod dece sa oštećenjem sluha u Lagosu.

Sva deca sa oštećenjem sluha u Lagosu su činila populaciju studije, dok je uzorak činilo 29 učenika, od kojih 15 dečaka i 14 devojčica, sa oštećenjem sluha. Za prikupljanje relevantnih podataka korišćen je Test sposobnosti rasuđivanja. U statističkoj obradi podataka korišćeni su aritmetička sredina, standardna devijacija, razlika srednjih vrednosti, analiza kovarijanse (ANCOVA) i najmanje značajna razlika (LSD).

Istraživanjem je utvrđeno da su i Montesori metod i metod Direktnog podučavanja efikasni u podučavanju učenika sa oštećenjem sluha, pri čemu je Montesori metod nešto efikasniji. Ovi nastavni metodi nisu značajno povezani sa polom učenika sa oštećenjem sluha. Preporučeno je da se Montesori didaktički metod koristi u podučavanju učenika osnovnoškolskog uzrasta jer podstiče aktivno učestvovanje u procesu učenja u vidu samousmeravanja i nezavisnosti, bez obzira na pol, intelektualne i ekonomske razlike.

Ključne reči: sposobnost rasuđivanja, Montesori didaktičko podučavanje, Direktno podučavanje, oštećenje sluha

Primljeno: 16.08 .2018$.

Prihvaćeno: 28.10.2018. 